\title{
The utility of using fiberoptic endoscopy in the diagnosis of nasal polyps
}

\author{
Ruth $\mathrm{Ko}^{1 *}, \mathrm{M}$ Cottrill ${ }^{2}, \mathrm{HK} \mathrm{Kim}{ }^{2,3}$ \\ From Canadian Society of Allergy and Clinical Immunology Annual Scientific Meeting 2010 \\ Victoria, Canada. 3-6 November 2010
}

\section{Background}

Nasal examination is important in assessing patients with rhinitis. Most allergists examine the nose using an otoscope (OT). Most do not perform fiberoptic rhinoscopy (FR). The purpose of this study is to determine the sensitivity for identifying nasal polyps (NP) with OT examination using FR findings as the gold standard.

\section{Materials and methods}

This study was performed in a referral allergist's practice in Ontario. In a prospective study, all patients with rhinitis symptoms had OT examination and FR. Patients who had NP identified with FR were included in the study. The findings of the OT examination were compared to the FR findings. Other data collected included allergy skin test results, presence of asthma, aspirin allergy, previous nasal surgeries, intranasal corticosteroid (INS) use and leukotriene receptor antagonist (LTRA) use.

\section{Results}

Eighty six patients were identified to have NP with FR. Forty nine patients (57\%) had NP identified by OT examination. Forty (47\%) of patients with NP had positive skin tests for at least one aeroallergen. Fifty-nine (68\%) had asthma, 13 (15\%) had an ASA allergy and 10 (12\%) had both conditions. Forty-eight (56\%) were using an INS and 9 (10\%) were on LTRA. Thirty-four (40\%) had previous surgery.

\section{Conclusions}

The OT examination had a $57 \%$ sensitivity. Therefore, in this study, $43 \%$ of patients with nasal polyps would have had their nasal polyps missed if FR was not performed.

* Correspondence: ruthetteko89@gmail.com

'University of Waterloo, Canada

Full list of author information is available at the end of the article
Author details

${ }^{1}$ University of Waterloo, Canada. ${ }^{2}$ University of Western Ontario, Canada.

${ }^{3}$ McMaster University, Canada.

Published: 4 November 2010

doi:10.1186/1710-1492-6-S2-P13

Cite this article as: Ko et al:: The utility of using fiberoptic endoscopy in the diagnosis of nasal polyps. Allergy, Asthma \& Clinical Immunology 2010 6(Suppl 2):P13.
Submit your next manuscript to BioMed Central and take full advantage of:

- Convenient online submission

- Thorough peer review

- No space constraints or color figure charges

- Immediate publication on acceptance

- Inclusion in PubMed, CAS, Scopus and Google Scholar

- Research which is freely available for redistribution
Biomed Central 